\title{
Electro-deposition of paint I ${ }_{667.634 .4 .087}^{u \text {. }}$
}

\author{
Minara Kazuyuki, Higashi Tatsuya, \\ Yukuta Tateki, Fukushima Takayasu,
}

Tokyo Laboratory, Osaka wanisu Co.*

(1) In order to prepare anti-corrosive paint for the use of electro-deposition the authors commenced study from the raw material of epoxy resin (Epikote, of Shell Chemical Company which was obtained by reacting epichlorohydrin with diphenylol propane.

(2) The epoxy resine was reacted at $50 \mathrm{deg}$. C for $2 \mathrm{hr}$. with phosphoric acid in a condition of 50 persent aceton solution. Authors obtained phosphoric acid ester of epoxy resin (I) after subsequent washing with water for the removal of unreacted phosphoric acid.

The same raw material epoxy resin was esterified with $\mathrm{C}_{18}$ fatty acids, those are saturated and unsaturated acids such as stearic acid, oleic acid and linolic acid, and the reaction product was then reacted with phosphoric acid at $50{ }^{\circ} \mathrm{C}$ for $2 \mathrm{hr}$. in the form of 50 percent acetone solution, then washed with water to remove unreacted phosphoric acid to obtain phosphoric acid ester of fatty acid modified eporxy resin (II). The fatty acid modified epoxy resin was reacted with phthalic anhydride at approximately $135^{\circ} \mathrm{C}$ for $30 \mathrm{~min}$ and the phthalic acid ester of fatty acid modified epoxy resin (III) was obtained.

Epoxy resin was reacted with dimer acid at $190-195^{\circ} \mathrm{C}$ for $40 \mathrm{~min}$. and the dimer acid ester of epoxy resin (IV) was obtained.

(3) As the contrasting test with the product in the method (2), a water soluble phenolic resin was prepared from phenol and formaline by the reaction under alkaline catalyst, after neutralization with ammonia.

(4) After electro-deposition on bare steel plate by means of constant-voltage method using water soluble resin solution obtained by the methods (2) and (3), the coated film was dried at $170^{\circ} \mathrm{C}$ for $30 \mathrm{~min}$. and the characteristics of the film were investrigated.

As a result, the type (I) among the (2) series was inferior in the electro-deposition property and in the physical properties, however, it was found that the former property can be improved in some extent by the addition of organic solvent to the resin solution, such as acetone.

(II), (III) and (IV) were excellent in general, but the water solubility was inferior for those epoxy resins having more than about 1800 molecular weight, and as for the type of modifying fatty acid, the unsaturated acids were superior in their film performances. As for the phenolic resin obtained in method (3), its electro-deposition property is superior, but was inferior in the film performance, and it blistered during $30 \mathrm{~min}$. in the boiling water. On the other hand, the resin solution obtained by the method (2) was stable for more than $7 \mathrm{hr}$. on the same condition by the parallel use of water soluble phenolic resin as the linking agent, obtaining an anticorresive film of electro-depositing nature having excellent adhesiveness and physical properties.

* 3-2 Naka-Kamata, Ôta-ku, Tokyo, Japan. 


\title{
電着用塗料に関する研究（第 $\mathbf{1}$ 報） $\begin{gathered}\text { UDC } \\ 667.634 .4 .087\end{gathered}$
}

\author{
三原一幸*・東 達弥* ・行田干城* ・福島隆康*
}

要

旨

電着用を目的として, 防セイ力のきわめて良好な塗膜を得るためにエポキシ樹脂を原料 とする塗料ビヒクルの合成研究を行ない耐沸騰水性が 3.5 時間の付着, 光沢の良好なるの を得た。

\section{緒言}

1809 年 Reuss ${ }^{1)}$ によって, コロイド粒子の電気泳動 性が発見されてより，この原理による金属の塗装や表面 処理的なことが種々研究されている ${ }^{2 \sim 50)}$ 。

しかしながら電着法に用いられる塗料を目的とした樹 脂合成の研究はなく, 油性系のものをエマルション化す るか, あるいはエマルション重合法による樹脂液, その 他水溶性アルキド樹脂, フェノール樹脂などが電着塗装 実験に用いられているに過ぎない $13,14,23,28,31,35,37,38,39) 。$

そこで筆者らは金属対する付着力, 耐水性, 耐薬品 性がきわめて良好であるエポキシ樹脂を原料とする電着 用塗料の製造研究を試みたので, その結果の一部につい て報告する。

本文

通常エポキシ樹脂**としてはエピクロールヒドリンと ジフェニロールプロパンとのポリ縮合反応によって得ら れるものが実用上最も多く用いられている。一般式は図 -1のように示される。<smiles>CCOC(O)CC(CC(C)(C)C)OC1CCC(C(C)(C)C2CCC(OC)CC2)CC1</smiles><smiles>COCCOC1CCC(C)(C2CCC(C)CC2)CC1</smiles>

図-1

昭 40.2. 18 受理

* 大阪 東京都大田区仲蒲田 $3 \sim 2$

** 商品名, エピコート樹脂（シェル化学社製）
ケトン，エステル，グリコールエーテルあるいはこれ らとトルェン，キシレンなどとの混合溶剤なぞには可溶 だが，水，アルコールなどには不溶である。

電着塗装法では, 塗料粒子のイオン荷電が必須の条件 そなるから水，アルコールなぞの極性溶㓮類に溶解する かエマルション分散せねばならない。

エポキシ樹脂の水溶化法としては次のことが考光られ る。すなわち, 多塩基酸によるエステル化物のアルカリ 塩で，この場合図-1 飞乱忊るエポキシ基と 2 級アルコ ールとでは，エステル化速度はエポキシ基の方が大だか ら, 樹脂/多塩基酸のモル比が $1 / 1$ では, 当然末端エポ キシ基に対する付加エステルとなる。（図-2）

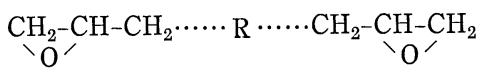

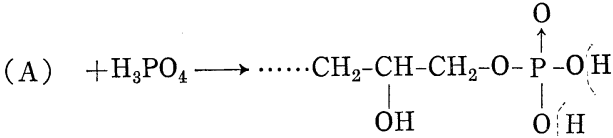

(B)

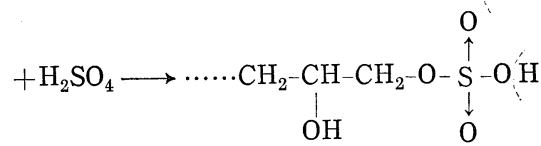

(C)<smiles>O=C(O)C1[C+]CCCC1C(=O)O</smiles>

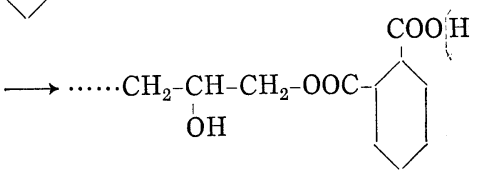

(D) $+\underset{\mathrm{CH}-\mathrm{COOH}}{\mathrm{CH}-\mathrm{COOH}} \rightarrow \cdots \cdot \mathrm{CH}_{2}-\mathrm{CH}_{\mathrm{O}}-\mathrm{CH}_{2}-\mathrm{OOC}-\mathrm{CH}$

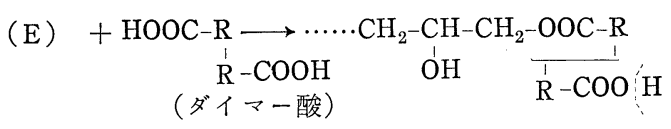
図-2 
いずれる半エステルであり，アルカリで中和すれば高 分子セッヶンの形になるから水溶化される。但しエステ ル化が進み過ぎると樹脂の橋カケを生ずるからゲル化す る。

これらエステル類が塗膜化された場合, 樹脂単独では 姵屾直となり屈曲などに弱いため, 通常の塗膜にあっては 脂肪酸エステルが用いられる。すなわち

$$
\begin{gathered}
\mathrm{CH}_{2}-\mathrm{CH}-\mathrm{CH}_{2} \cdots \cdots \cdots-\mathrm{CH}_{2}-\mathrm{CH}^{\prime} \mathrm{O}^{\prime} \\
\stackrel{\mathrm{CH}}{\mathrm{CH}_{2}}+\mathrm{RCOOH} \\
\mathrm{R}-\mathrm{COO}-\mathrm{CH}_{2}-\mathrm{CH}-\mathrm{CH}_{2} \cdots \cdots \cdots \mathrm{CH}_{2}-\mathrm{CH}_{-}-\mathrm{CH}_{2} \\
\mathrm{OH}
\end{gathered}
$$

したがって電着のための水可溶化法と, 電着された塗 膜の性能を考吕る時,

(a) エポキシ樹脂を脂肪酸によりエステル化し

(b) ついで，このエポキシ樹脂一脂肪酸エステル化物 を多塩基酸でェステル化したのち，アルカリ中和す れば水可溶性の脂肪酸変性水可溶性エポキシ樹脂と なる。

この時理論的にはエポキシ樹脂一脂肪酸エステルに和け る脂肪酸量はエポキシ樹脂中 1 ケの一OH 基を残す以外 のすべてをエステル化するまでのモル量を使用すること はできるが，この時の親水基は親水性がきわめて大でな くては水可溶化にできない。しかし水一アセトンなぞの 上万な水可溶性有機溶剂を使用すれば溶解する。槽内に 物ける通電性には水ーアセトン,グリコールエーテル類 の混液は大きい影響を与兄ない。

本実験では, 脂肪酸としてはステアリン酸, オレイン 酸，リノール酸を，多塩基酸としてはリン酸，重合脂肪 酸（ダイマ一酸），無水フタル酸を用い，エポキシ樹脂 は種々の縮合度の平均分子量の異なるものを使用して電 着性の良否，塗膜性能などそついて調べた。

\section{実 験 の 部}

\section{1) 原 料}

(A) エポキシ樹脂はシエル化学社製のエピコート樹脂

\begin{tabular}{|c|c|c|c|c|}
\hline \multicolumn{5}{|c|}{ 表-1 } \\
\hline エポキシ樹脂 & & $\begin{array}{l}\text { ×1 } \\
\text { エポキシ } \\
\text { 酸素 }\end{array}$ & 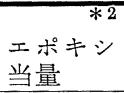 & $\begin{array}{l}\text { 争 } \\
\text { 見かけの } \\
\text { 分子量 }\end{array}$ \\
\hline エピコート\# & \# 828 & 7.9 & 202 & 404 \\
\hline "I & \# 834 & 6.2 & 260 & 520 \\
\hline "I & \# 1001 & 3.2 & 500 & 1000 \\
\hline "1 & \# 1004 & 1.7 & 940 & 1880 \\
\hline " & \# 1007 & 0.9 & 1780 & 3560 \\
\hline
\end{tabular}
を用いた。性状は次のと晾りである。

注） *1 塩酸ージオキサン法で測定した *2*1より計算によって得た *3*1より計算によって得た
(B) ステアリン酸，オレイン酸、リノール酸などはい ずれも化学用純品を用いた。

ステアリン酸 中和価 196 (198)

オンイン酸 中和価 200 (199) ヨウ素価 93( 91)

リノール酸 中和価 202 (201) ヨウ素価 181(181)

（）内は計算值

(C)リン酸特よび無水フタル酸はいずれも市販の化学 用 1 級品を用い，重合脂肪酸は米国のエメリー社製エム ポール 1022 (酸価 189.0，ケン化価 196.4，モノマー $3 \%$ ，ダイマー $71 \%$ ，トリマー $26 \%$ ）を用いた。

2）エポキシ樹脂と脂肪酸，リン酸などとの反応

(A) エポキシ樹脂とリン酸との反応

$50 \%$ エポキシ樹脂アセトン溶液 $100 \mathrm{~g}$ を $\mathrm{N}_{2}$ ガス導入 管, カクハン機, 温度計, 還流冷却管をつけた $500 \mathrm{cc}$ 容 の四つ口丸底フラスコ中に入れ， $\mathrm{N}_{2}$ ガスを $30 \sim 40 \mathrm{cc} /$ min の流速で吹込みつつかきまぜながら，室温（20〜 $\left.25^{\circ} \mathrm{C}\right)$ で，リン酸を加えたのち $50^{\circ} \mathrm{C}$ に加温し 2 時間反 応させた。のち減圧下に加温しながら大部分のアセトン を留去し，ついで未反応のリン酸を除去するため温水を 加光て水洗し, 洗液がリトマスで中性になるまで反復し たのち，減圧下に加温して乾燥しエポキシ樹脂のリン酸 エステルを得た。

(B) エポキシ樹脂と脂肪酸掞よびリン酸との反応 エポキシ樹脂（固形のものは粉砕した） $50 \mathrm{~g}$ と, 脂肪

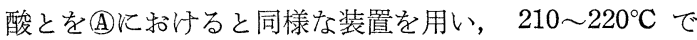
加熱かきまぜを行なって内容物の酸価が 3 以下になるま でェステル化反応を行ない，ついで室温にしてからこれ に約同量のアセトンを加えて脂肪酸エステル化物を溶解 しこれを $50^{\circ} \mathrm{C}$ に加温しつつリン酸を加えて反応させ た。以下は(A)と同様に精製して目的物を得た。

(C) その他の反応物

(a) 多塩基酸として無水フタル酸を用いた場合は(B) と同様に $210 \sim 220^{\circ} \mathrm{C}$ でエポキシ樹脂の脂肪酸エステ ルをまず作り，ついで温度を $130^{\circ} \mathrm{C}$ 前後に下げてから 無水フタル酸を涯加し $130 \sim 140^{\circ} \mathrm{C}$ で 30 分間反応を 行なった。

(b) 重合脂肪酸（ダイマー酸）では，エポキシ樹脂 と重合脂肪酸とを混合し，190 $195^{\circ} \mathrm{C} て ゙ ~ 40$ 分間反応 を行なった。

以上の実験に和ける混合割合と中間生成物和よび最終 生成物の化学的性状を表-2 に，その赤外線吸収スペク トルを図-3 に示す。

3）合成物水性液の性状

2) 飞よって得た乾燥合成物を，その重量の約 $1 / 2$ 量 の水を加えてかきまぜつつ，これにトリエタノールアミ 
表-2

\begin{tabular}{|c|c|c|c|c|c|c|c|c|c|c|c|}
\hline \multirow{3}{*}{$\begin{array}{l}\text { 実 } \\
\text { 験 } \\
\text { No. }\end{array}$} & \multirow{3}{*}{$\begin{array}{l}\text { エポキシ } \\
\text { 樹脂の種 } \\
\text { 類 }\end{array}$} & \multicolumn{6}{|c|}{ 原料配合割合（モル／1モルエポキシ樹脂） } & \multirow{2}{*}{\multicolumn{2}{|c|}{$\begin{array}{l}\text { エポキシ樹脂一 } \\
\text { 脂肪酸反応物 }\end{array}$}} & \multirow{2}{*}{\multicolumn{2}{|c|}{ 最終生成物 }} \\
\hline & & 脂 & 肪 & & \multicolumn{3}{|c|}{ 多 塩 基 酸 } & & & & \\
\hline & & $\begin{array}{l}\text { ステアリ } \\
\text { ン酸 }\end{array}$ & \begin{tabular}{|l|} 
オレイン \\
酸
\end{tabular} & \begin{tabular}{|l|l|l}
1 \\
酸
\end{tabular} & リン酸 & $\mid$\begin{tabular}{|l|l|} 
ダイマー酸 \\
\end{tabular} & \begin{tabular}{|l|} 
無水フタ \\
ル酸
\end{tabular} & 酸 価 & $\begin{array}{l}\text { エポキシ* } \\
\text { 酸素(\%) }\end{array}$ & 酸 価 & $\begin{array}{l}\text { エポキシ* } \\
\text { 酸素(\%) }\end{array}$ \\
\hline 1 & $\begin{array}{c}(50 \mathrm{~g}) \\
1007\end{array}$ & - & - & - & $\begin{array}{l}2 \\
(3.2 \mathrm{~g})\end{array}$ & - & - & - & - & 19 & 0 \\
\hline 2 & 1004 & - & - & - & $(6.1 \mathrm{~g})$ & - & - & - & - & 52 & 0 \\
\hline 3 & 1004 & - & - & $\frac{1}{(7.4 \mathrm{~g})}$ & $\begin{array}{l}2 \\
(6.1 \mathrm{~g})\end{array}$ & - & - & 1 & $\begin{array}{c}0.73 \\
(0.74) \\
\end{array}$ & 27 & 0 \\
\hline 4 & 1001 & - & - & - & $\begin{array}{l}2 \\
(11.6 \mathrm{~g})\end{array}$ & - & - & - & - & 60 & 0.4 \\
\hline 5 & 1001 & - & - & $(14 \mathrm{~g})$ & $(11.6 \mathrm{~g})$ & - & - & 1 & $\begin{array}{c}1.0 \\
(1.2) \\
\end{array}$ & 46 & 0.1 \\
\hline 6 & 1001 & $\begin{array}{c}1 \\
(14 \mathrm{~g})\end{array}$ & - & - & $\begin{array}{c}2 \\
(11.6 \mathrm{~g})\end{array}$ & - & - & 1 & $\begin{array}{l}1.1 \\
(1.2)\end{array}$ & 48 & 0 \\
\hline 7 & 1001 & - & - & - & - & $\begin{array}{l}1.5 \\
(42 \mathrm{~g})\end{array}$ & - & - & - & 50 & 1.0 \\
\hline 8 & 1001 & - & - & $\begin{array}{l}1 \\
(14 \mathrm{~g})\end{array}$ & - & - & $\begin{array}{c}1.5 \\
(11.1 \mathrm{~g})\end{array}$ & 1 & $\begin{array}{l}1.0 \\
(1.2)\end{array}$ & 57 & 0.8 \\
\hline 9 & 834 & - & - & $\begin{array}{c}1 \\
(27.5 \mathrm{~g})\end{array}$ & $(11.3 \mathrm{~g})$ & - & - & 1 & $\begin{array}{l}1.8 \\
(2) \\
\end{array}$ & 61 & 0 \\
\hline 10 & 834 & - & $\begin{array}{l}1 \\
(27.5 \mathrm{~g})\end{array}$ & - & $(11.3 \mathrm{~g})$ & - & - & 1 & $\begin{array}{l}1.8 \\
(2)\end{array}$ & 68 & 0 \\
\hline 12 & 828 & - & - & $\begin{array}{r}0.2 \\
(7 \mathrm{~g}) \\
\end{array}$ & $(14.3 \mathrm{~g})$ & - & - & 3 & $\begin{array}{c}5.1 \\
(5.5) \\
\end{array}$ & 65 & - \\
\hline 13 & 828 & - & - & $\begin{array}{c}1 \\
(35 \mathrm{~g})\end{array}$ & $(1 \dot{4} .3 g)$ & - & - & 2 & $\begin{array}{c}2.1 \\
(2.3) \\
\end{array}$ & 70 & 0.4 \\
\hline
\end{tabular}

注）エポキシ樹脂の量はいずれも $50 \mathrm{~g} \quad *$ ）塩酸ージオキサン法による エポキシ酸素\%の（）内は計算值

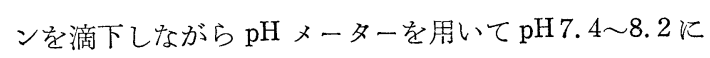
すると水可溶もしくはエマルションになる。その後さら に水を加えて 25～50\%の不揮発分を含先水性液とし

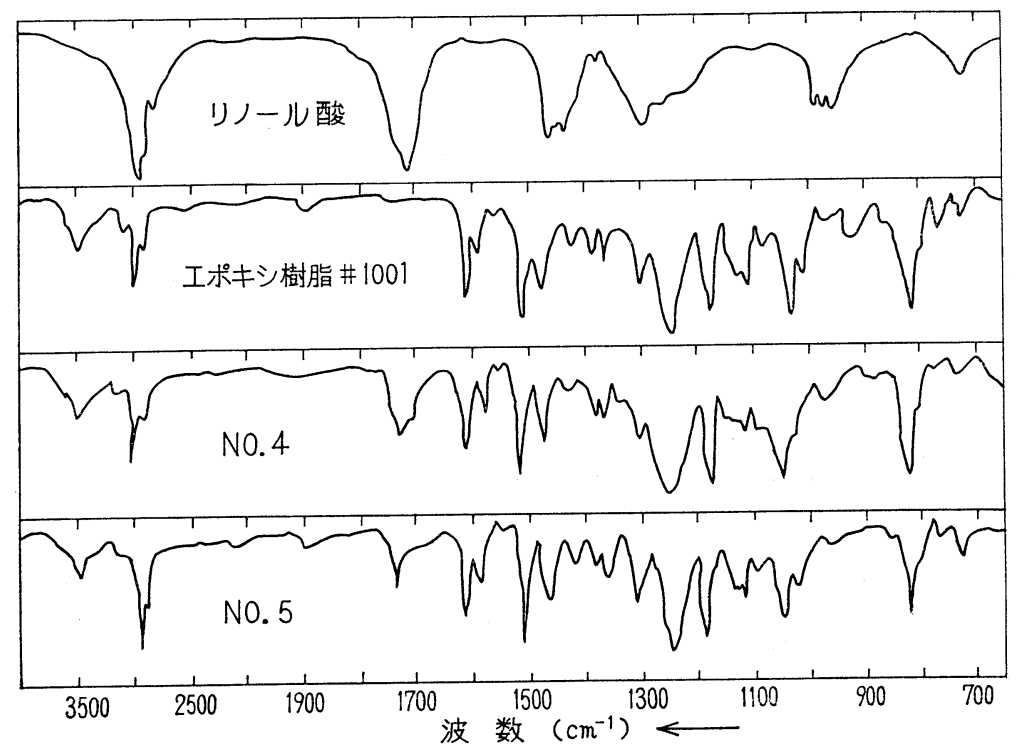

図-3 (A)
た。これらの性状を表-3 に示す。

表 -2 拈よび表-3 の結果より，この方法では原料とし たエポキシ樹脂の分子量が高いNo.1，2，3では水単独， では溶解しない。しかしブタノ ール，アセトン，セロソルブな どの水可溶有機溶剤を添加する と溶解する。

\section{4）軟鋼板に対する電着性 \\ (A) 実験装置}

シリコン整流器（交流側 100 $\mathrm{V}, 18 \mathrm{~A}$, 直流側 $6 \sim 75 \mathrm{~V}, 15$ A) 電圧計 $(100 \mathrm{~V})$ 電流計 $(1$ $\mathrm{A} \times 3$ ) ガラス槽（タテ $16 \mathrm{~cm}$, ヨコ $21 \mathrm{~cm}$, 高サ $26 \mathrm{~cm})$, カ クハン機, 温度計 $\left(100^{\circ} 1 / 1\right)$ を用い, 図-4のような装置を作 った。Ө極板, 円極板（被塗装 物）には $0.8 \mathrm{~mm}$ 厚のみがき軟 鋼板を用いた。

(B) 電着実験の結果

表-3 に持ける 合成物の 水溶 


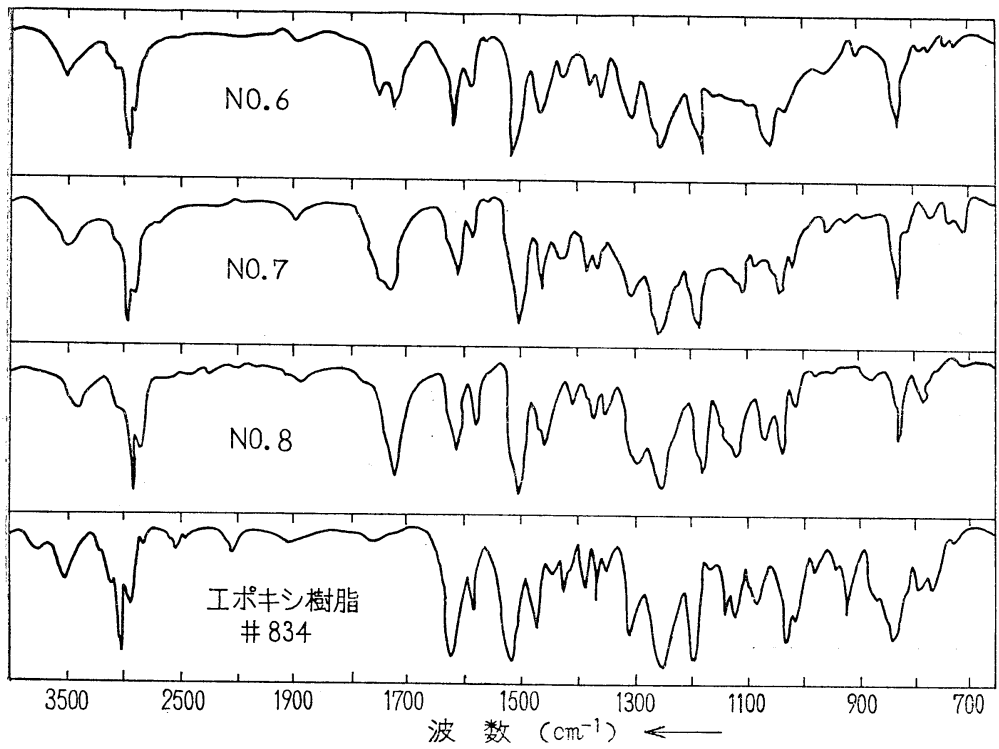

図-3 (B)

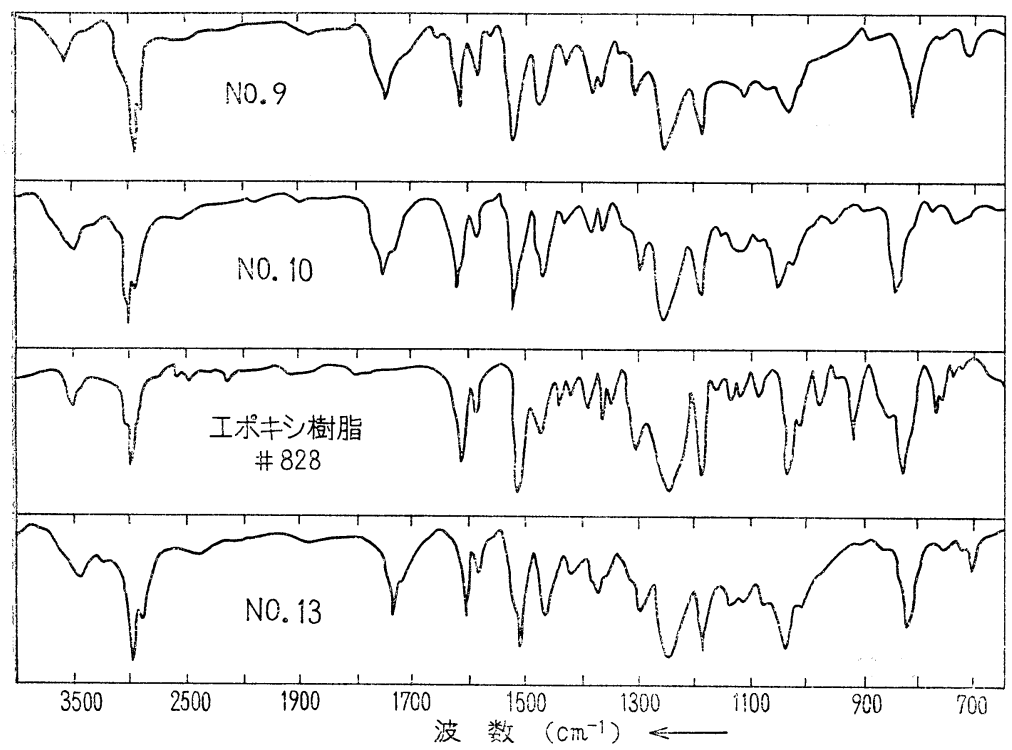

図-3 (C)

液を用いて電着実験を行なった。な执実験 No. 1〜3の ものにまっては水に不溶なので除外した。

(a) 電圧の関係

実験番号 4，5，6，9，10，13 3 ）の方法によって 得た微アルカリ水性液を原液とし，これを蒸留水で不揮 発分 $10 \%$ となるように調製し， $5 l$ 容ガラス槽中に $3 l$ 入れ電極間隔 $15 \mathrm{~cm}$, 温度 $20^{\circ} \mathrm{C}$, 定電圧法によって電 流密度の変化を測定した。結果を図-5に示す。

図-5 の結果より，得られた合成物の種類によって電 王低下の樣相には相当差があることがわかる。また初期
電圧が低いと時間の経過による 電流低下は, 初期電圧の高いも のよりはゆるやかであるが，一 定時間の経過後はいずれも一般 に初期電圧の高低には関係なく ほぼ等しくなった。

(b) 温度の影響

実験番号 $5 ， 6 ， 9 ， 10$ のも について, 不揮発分 $10 \%, 5 l$ 容ガラス槽中に $3 l$ の塗料液を 入れ, 電極間隔 $15 \mathrm{~cm}$ 定電圧 $(30$ V) 法によって温度の差による 電流変化を測定した結果を図-6 に示す。

图-6 亿括ける実験結果では， 温度による電流変化はさほど大 きいものではない。いずれも温 度が高いと電流は高くなる。し かし得られた塗面は温度が高い と粗となり, 光沢性の平滑面に はならない。

\section{(c) 不揮発分の関係}

実験番号 4 のものについて, 不揮発物量の差による電流変化 について検討して見た。実駼方 法は(b)と同じで定電圧 $(30 \mathrm{~V})$ で行なった。結果を図-7 に示 于。

図-7 から不揮発物量が多く なると, 初期電流は当然大であ ることが見られるが，電流の低 下性は $15 \%$ を境界にして，や や異なることが見られる。塗面 のなめらかさなどから考觉てこ の系の液では $15 \%$ 前後が限界 でこれ以下の濃度では塗膜がうすく，これ以上では次第 に粗面であった。初期電圧の差, 樹脂の種類によって当 然これらのことは変る因子であるが，一定の実験条件下 での電流曲線によっても最適の濃度を知ることができる といえる。

(d) $\mathrm{pH}$ の関係

実験番号 9 のものについて，不揮発物量 $10 \%$ で $\mathrm{pH} *$ の差による電流変化を実験方法 (b) と同じ方法で定電圧 $(30 \mathrm{~V})$ で調ベた。結果を図-8 に示す。

* 東亜電波社製 $\mathrm{pH}$ メーター HM-5”a 型 


\begin{tabular}{|c|c|c|c|c|c|c|}
\hline \multicolumn{7}{|c|}{ 表-3 } \\
\hline $\begin{array}{l}\text { 実験 } \\
\text { No. }\end{array}$ & $\begin{array}{l}\text { エポキ } \\
\text { シ樹脂 } \\
\text { の種類 }\end{array}$ & $\mathrm{pH}$ & \begin{tabular}{|l} 
不揮発 \\
分
\end{tabular} & $\begin{array}{l}\text { 粘度 } \\
20^{\circ} \mathrm{C}\end{array}$ & ${ }_{20^{\circ}}$ 重 & 外 観 \\
\hline 1 & 1007 & - & - & - & - & 不 \\
\hline 2 & 1004 & - & - & - & - & 不 \\
\hline 3 & 1004 & - & - & - & - & 不＼cjkstart溶 \\
\hline 4 & 1001 & 7.6 & 40 & $Z_{4}$ & - & 透 明 液? \\
\hline 5 & 1001 & 7.8 & 25 & $\mathrm{U}$ & 1. 048 & 乳白色液： \\
\hline 6 & 1001 & 8.1 & 40 & - & - & 乳白色液 \\
\hline 7 & 1001 & 8.0 & 40 & $\mathrm{~N}$ & 1.025 & 透 明液 \\
\hline 8 & 1001 & 7.4 & 50 & $Z_{2}$ & 1. 155 & 透 明 液 \\
\hline 9 & 834 & 8.2 & 40 & $Z_{4}$ & 1. 049 & 透明液 \\
\hline 10 & 834 & 7.9 & 40 & $\mathrm{U}$ & 1. 071 & 透 明 液 \\
\hline 12 & 828 & 7.7 & 40 & $Z$ & 1. 064 & 透 明 液 \\
\hline 13 & 828 & 7.4 & 25 & $X-Y$ & 1. 048 & 乳白色液 \\
\hline
\end{tabular}

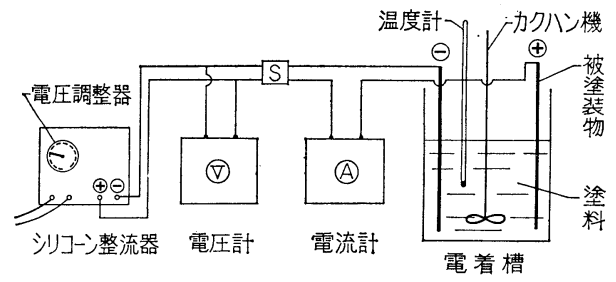

図-4

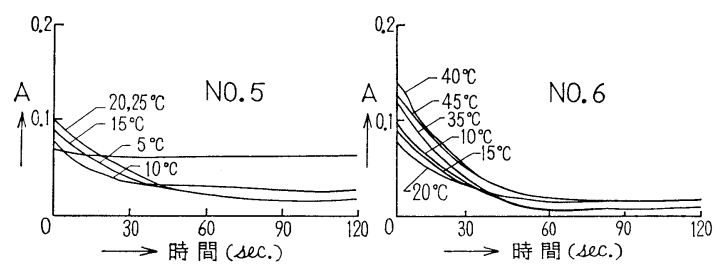

図-6（A） 温度 の 影 響

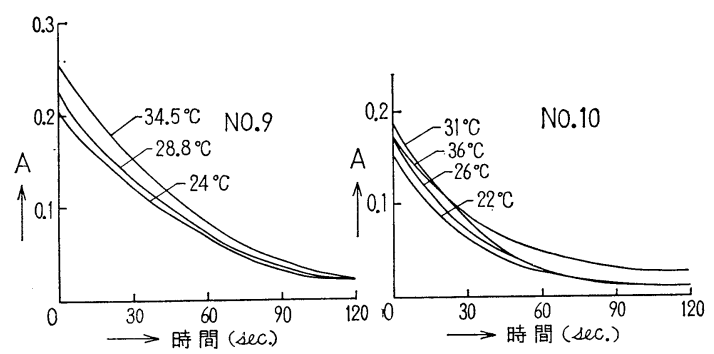

図-6（B）温度の影響

図-8 によると，pH 8.55 によるものがわずかに差が あるのみで, $\mathrm{pH} 7.55,8.1 ， 9.05$ は同一である。すな わち $\mathrm{pH}$ の差による電流変化はアルカリ側では余り大き な差はない。

(e) 有機溶剤添加の影響

実験 No. 4 のものについて, 水溶性有機溶剂として,
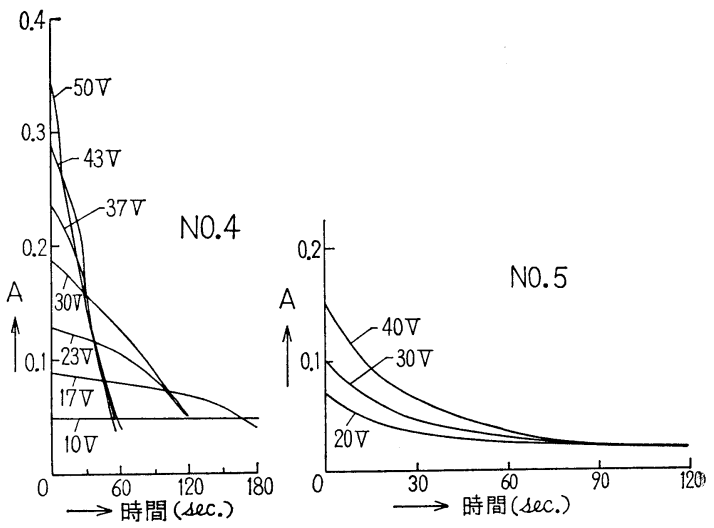

図-5（A）電 圧-電 流 の関 倸
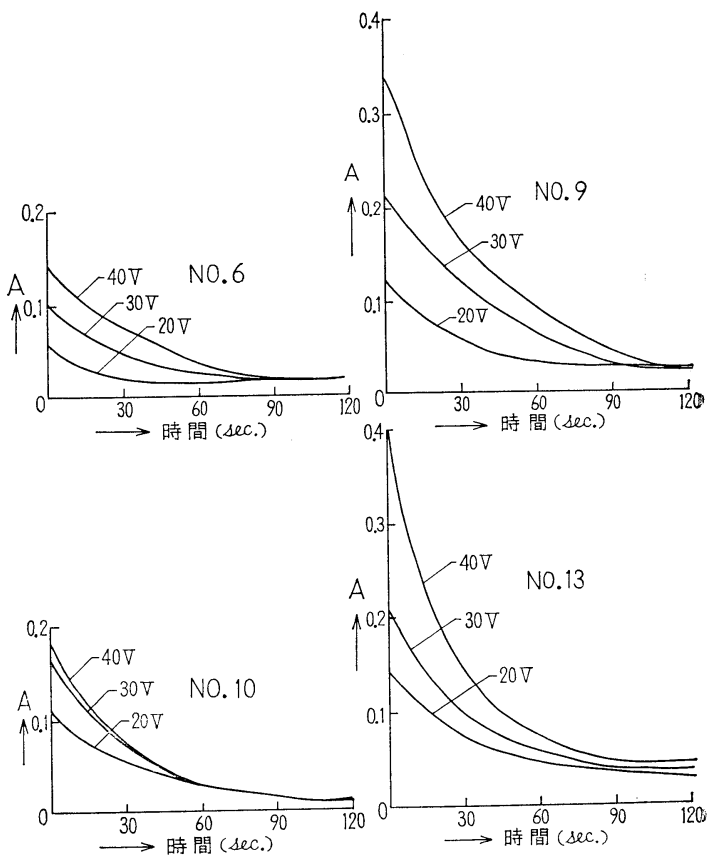

図-5 (B) 電 圧-電 流 の関 係

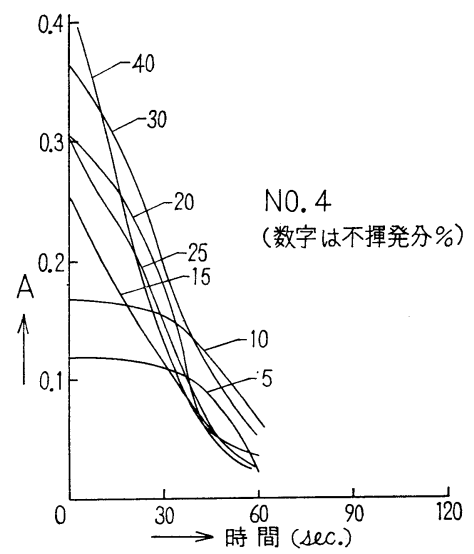

図-7

不揮発分の関倸 


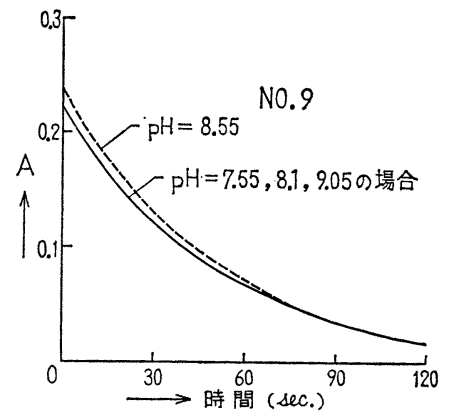

図-8 $\mathrm{pH}$ の関係

アセトン, メタノール, n-ブタノール, イソプロパノー ル，ブチルセロソルブを選び，電着液中に混入された有 機溶剤による電流変化を調べた。結果を図-9 に示す。

図-9 は No. 4 樹脂の水性原液をまず水でうすめて $15 \%$ とし，これに所定量の有機溶剤を加えた時の電流変 化と電着塗膜を $170^{\circ} \mathrm{C}-20$ 分間加熱乾燥した時の 塗膜 付着量 $\left(\mathrm{g} / \mathrm{cm}^{2}\right)$ を示したものである。

図-9 によれば，イソプロパノールをこの 条件の 実験 下では，12.5\%添加したものが最も良好である。有機溶 剤量が大になると，電流変化が見られないのは，金属面 に樹脂分が十分に電着されないためである。また一般に
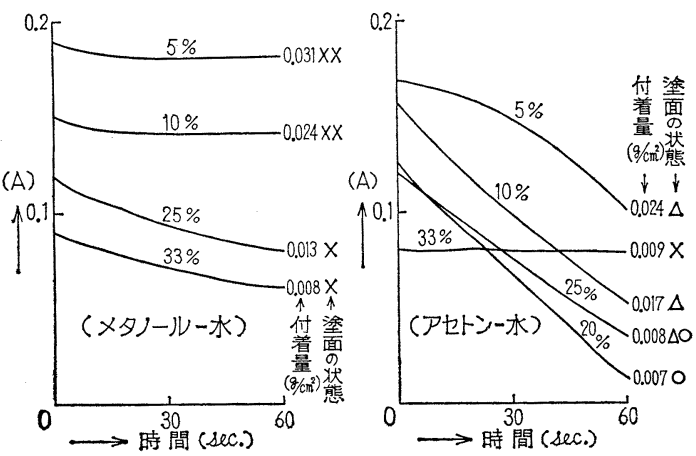

図-9 (A)
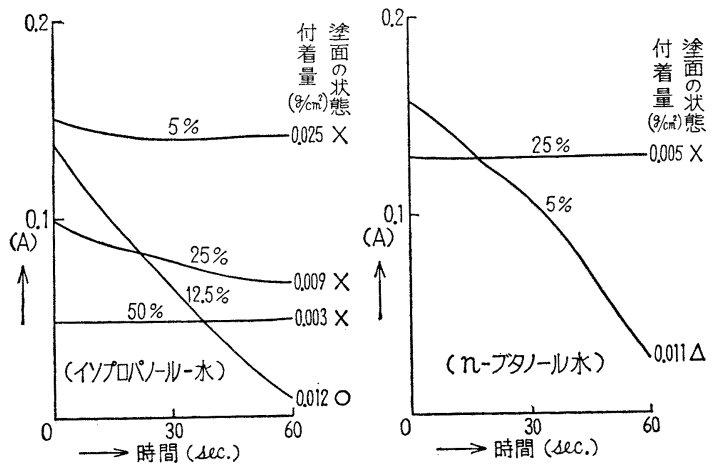

図-9 (B)

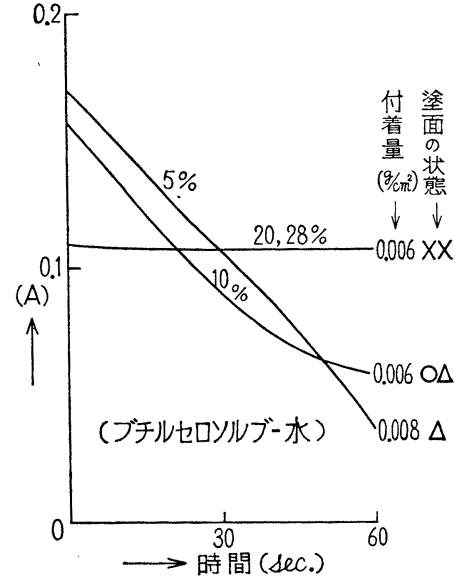

図-9 (C)

添加量が増加すると, 初期電流は必然的に小さくなる。 このことから, 有機溶剂類の添加は, 水中に分散された 樹脂分が水系より分離しないための安定剤としての意味 と樹脂分のイオン性解離を䄮制するためと, 電着塗面の 凹凸をわずかに溶解して滑面にするために加えるのであ るならば，きわめて効果的であることがわかる。

表-4 スローイングパワー性

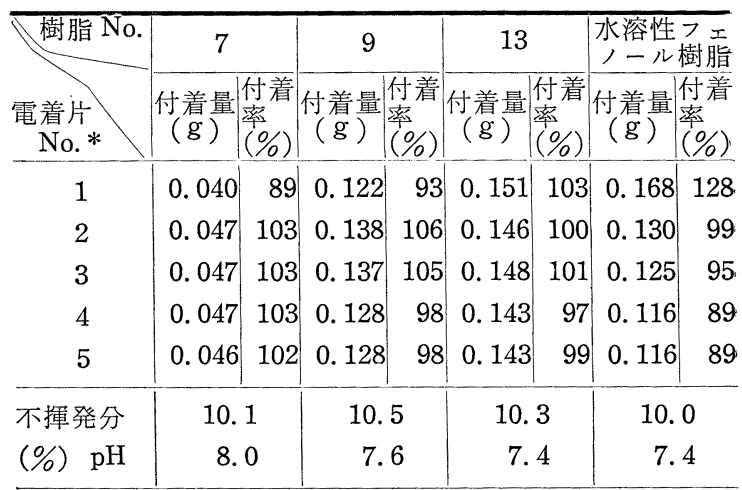

* Ө極に近い試験片を（1）とした

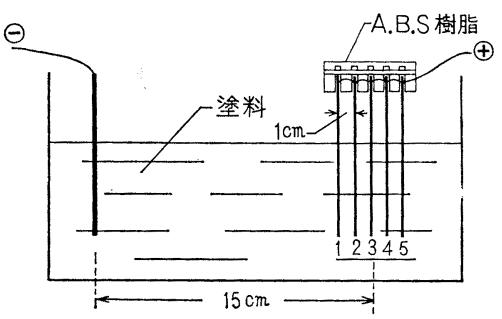

図-10

(f) スローイングパワー性

実験番号 7，9，13 のものについて，J.R. Berry によ る方法を応用してスローイングパワー性を調ベた ${ }^{37)}$ 。す 


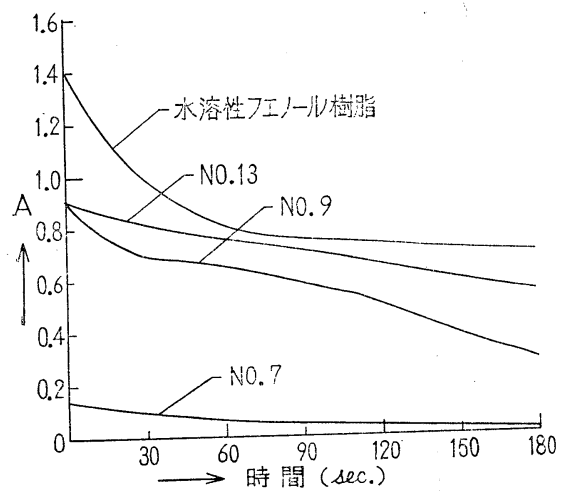

図-11

を図-11 に示した。

表-4 の結果汇よれば，いずれもスローイングパワー 性は良好であると考光られる。

(8) 合成物水溶液による電着塗膜の性状

不揮発分 $10 \%$ の水溶液により, $30 \mathrm{~V}, 2$ 分間, 極間 距離 $20 \mathrm{~cm}$, 液温 $20 \pm 2^{\circ} \mathrm{C}, 0.8 \times 50 \times 150 \mathrm{~mm}$ の軟鋼板 による電着塗膜を十分に水洗した後, $170^{\circ} \mathrm{C} 30$ 分の加 熱乾燥を行なったものについて，その性状を調べた。結 果を表-5 亿示す。

表-5 の結果より No. 7, 12 が耐沸騰水に対しては良 好である。このうち No.7 は No.12 飞比べて塗膜の着 色性は少ないが，屈曲は弱い。電着塗装は主として下塗 りとしての価值があるから，着色性はそれぼ゙重

表-5

\begin{tabular}{|c|c|c|c|c|c|c|c|c|}
\hline \begin{tabular}{c|} 
樹脂 \\
$\Phi$ \\
No: \\
\end{tabular} & \begin{tabular}{|l|} 
電着 \\
\end{tabular} & $\begin{array}{l}\text { 塗膜** } \\
\text { の } \\
\text { 着色性 }\end{array}$ & \begin{tabular}{|l|} 
膜厚 \\
$(\mu)$
\end{tabular} & 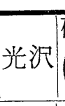 & 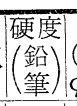 & $\begin{array}{l}\text { 屈曲* } \\
(2 \mathrm{~mm} \\
\phi)\end{array}$ & $\begin{array}{l}\text { ゴベン } \\
\text { 目セ口 } \\
\text { テープ }\end{array}$ & 耐沸騰水性 \\
\hline 4 & $x$ & + & 12 & 0 & $2 \mathrm{H}$ & $\times$ & $100 / 100$ & 10分一-(白 化) \\
\hline 5 & $\triangle$ & ++ & 14 & 0 & $2 \mathrm{H}$ & 0 & $100 / 100$ & 10分一(白 化) \\
\hline 6 & $\triangle$ & + & 14 & 0 & $4 \mathrm{H}$ & $x$ & $0 / 100$ & 10 分一-(白 化) \\
\hline 7 & $\bigcirc$ & ++ & 13 & 0 & $2 \mathrm{H}$ & $x$ & $100 / 100$ & 200 分一(軟 化) \\
\hline 8 & $\times$ & + & 15 & 0 & $2 \mathrm{H}$ & $x$ & $50 / 100$ & 120分一（軟 化) \\
\hline 9 & 0 & + & 15 & 0 & $2 \mathrm{H}$ & 0 & $100 / 100$ & 40分一(白 化) \\
\hline 10 & 0 & +++ & 14 & 0 & $4 \mathrm{H}$ & 0 & $100 / 100$ & 25分一（白 化) \\
\hline 12 & 0 & +++ & 12 & 0 & $2 \mathrm{H}$ & O & $100 / 100$ & 200分一（敷 化) \\
\hline 13 & $\triangle$ & +++ & 13 & 0 & $2 \mathrm{H}$ & 0 & $100 / 100$ & 120 分一(フクレ) \\
\hline
\end{tabular}

$* \times$ 不良, $\triangle$ 可 $\bigcirc$ 良を示す

** 十 の多い注ど濃色を示す。

なわち $50 \times 75 \times 0.6 \mathrm{~mm}$ 鋼板 5 枚を $1 \mathrm{~cm}$ の間隔に垂直 そ並べ, 導線で各々は連絡して甲極とし, $\ominus$ 極より 3 枚 目の極板を $\ominus$ 極との距離が $15 \mathrm{~cm}$ とし， $52 \mathrm{~V} ， 3$ 分間 の電着を行なった後試験片を引き上げ, 蒸留水で十分に 洗浄したのち, $150^{\circ} \mathrm{C}$-30 分の加熱乾燥を行なった。な 扣参考のために後記の方法によって得られた水溶性フェ ノール樹脂をスローイングパワー性が良いとされている ので同時に行なった。結果を表-4 亿示す。また実験装

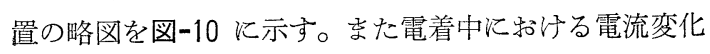

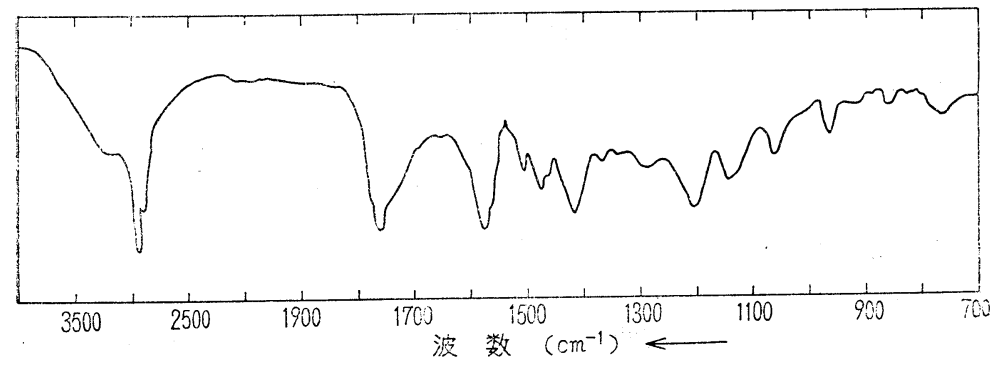

図-12 水溶性フェノール樹脂の IR スペクトル
要な困子とは考光られず，むしろ付着性と沸騰水 に対する抵抗性の方が防セイの面からは重要であ ると考光られる。したがってNo.12 の合成物が 電着用塗料としては良好であると考学られる。

5）水溶性フェノール樹脂の合成

市販化学用フェノール, $188 \mathrm{~g}$ と $37 \%$-ホルマ リン $33 \mathrm{~g}$ とを混合し, $1 l$ 容三つロフラスコ中に 入れ, $20 \%$ 水酸化ナトリウム水を加光て $\mathrm{pH} 8.0$ 〜8.5 にし，加熱かきまぜを行なって 90〜 $100^{\circ} \mathrm{C}$ で 2 時間反応させると，淡黄褐色の粘稠液とな る。ついでこのものに $10 \%$ 一塩酸を少量加えて $\mathrm{pH}$ を 4.5 とし，さらに水 $400 \mathrm{cc}$ を加えてかき まぜ, 分液濾斗中に移して一夜間放置すると二層 となるので, 下層の水層部をとり去り, ついで樹脂層を $60^{\circ} \mathrm{C}$ の温水で 5 回水洗したのち, イソブタノール 100 cc を加えて溶解したのち $\mathrm{pH} 8.0$ ８.5 ヒアンモニア水 で調整した水を加えて $50 \%$ 水溶液とした。不揮発分 51 $\%$, 粘度 $\mathrm{D}-\mathrm{H}, \mathrm{pH}=8.0$ 樹脂の $\mathrm{IR}$ スペクトルを図-12 飞示す。

6）水溶性フェノール樹脂の電着性と合成物との混合 による電着塗膜

一5）飞よって得た水溶性 フェノール樹脂 水溶液単独の もの，拈よびこれを先に得たエポキ シ樹脂系合成物のうち No. 8, 9, 13 を選び，不揮発分で $5 / 5,7 / 3$ （エ ポキシ樹脂誘導体／水溶性フェノー ル樹脂）比に混合した水溶液につい て不揮発分 $10 \%, 30 \mathrm{~V}-1$ 分, 液温 $20 \pm 2^{\circ} \mathrm{C}$ ，極間距離 $20 \mathrm{~cm}$ で電着叙 装を行ない，のち十分に水洗し, 150 ${ }^{\circ} \mathrm{C} \sim 30$ 分間の加熱乾燥を行なった ものについてその叙膜の性状を調べ 
表-6

\begin{tabular}{|c|c|c|c|c|c|c|c|}
\hline $\begin{array}{c}\text { 合成物の } \\
\text { No. }\end{array}$ & \begin{tabular}{|l} 
混合比合成 \\
物 / フェ \\
$-ル \mathrm{R}$
\end{tabular} & $\begin{array}{c}\text { 電着 } \\
\text { の } \\
\text { 状態| }\end{array}$ & 光沫 & 着色性 & 硬度 & $\begin{array}{l}\text { I゙バン目 } \\
\text { セロテー } \\
\text { プ }\end{array}$ & 耐沸騰水性 \\
\hline 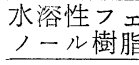 & - & (C) & (C) & $+t+$ & $2 \mathrm{H}$ & $100 / 100$ & 30 分 (フクレ) \\
\hline \multirow{3}{*}{ No. 8} & $5 / 5$ & $\triangle$ & $x$ & ++ & $2 \mathrm{H}$ & $100 / 100$ & 420 分以上 \\
\hline & $7 / 3$ & $\triangle$ & $x$ & ++ & $2 \mathrm{H}$ & $100 / 100$ & 150 分 (フクレ) \\
\hline & No.8のみ & $\Delta$ & $\times$ & + & $2 \mathrm{H}$ & $100 / 100$ & 100 分 (フクレ) \\
\hline \multirow{3}{*}{ No. 9} & $5 / 5$ & (a) & (a) & +++ & $2 \mathrm{H}$ & $100 / 100$ & 30 分 (フクレ) \\
\hline & $7 / 3$ & (C) & (C) & ++ & $2 \mathrm{H}$ & $100 / 100$ & 30 分 (フクレ) \\
\hline & No. 9 のみ & $\bigcirc$ & $\bigcirc$ & + & $2 \mathrm{H}$ & $100 / 100$ & 30 分 (フクレ) \\
\hline \multirow{3}{*}{ No. 13} & $5 / 5$ & (C) & (C) & ++ & $2 \mathrm{H}$ & $100 / 100$ & 20 分 (白 化) \\
\hline & $7 / 3$ & (a) & (C) & ++ & $2 \mathrm{H}$ & $100 / 100$ & 30 分 (フクレ) \\
\hline & No. 13 のみ & 0 & O & + & $2 \mathrm{H}$ & $100 / 100$ & 15 分 (フクレ) \\
\hline
\end{tabular}

10) B. Dogadkin, D. Sandomirsky, Rev. Gen. Caout, 10, 17 (1933) ; Rubber Chem. and Tech., 7, 314 (1934).

11) D. F. Twiss, J I. E. E., 75, 481 (1934).

12) C. F. Flint, "The Chemistry and Technology of Rubber Latex" Chapman and Hall, London, 1938.

13) W. P. Thompson \& Co., Brit. Patent 455, 810 (1936) Page White \& Farrer, Brit. Patent 496, 945 (1938).

14) H. C. Harmaker, Trans. Faraday Soc., 35, 279 (1940).

15) A. Gemant, Ind. Eng. Chem., 31, 1233 (1939).

16) Derjaquin and London, Acta $\mathrm{Ph}$ ysico Chim., 24, 633 (1944).

た結果を表-6 に示す。

表-6 の結果から電着性とその面の光沢，付着性なぞ はきわめて良好であることがわかるが，沸騰水比対する 抵抗性は, 水溶性フェノール樹脂は 30 分でフクレを全 面に発生すると共に軟化きれるので，防セイ面から考光 た場合実用性はない。No. 8 の樹脂で, $5 / 5$ 比に水溶性 フェノール樹脂を混合して得た電着塗面の耐沸騰水性が きわめて良いのは, 通常のスプレ一塗装用の場合, エポ キシ樹脂 /フェノール樹脂 $=8 / 2$ 比が大略として良好な 塗膜になることから推定して電着速度がこの実験の場 合，合成物の方がやや早くなり結果的に上記 $8 / 2$ 比に近 似の樹脂組成になったためであるうと推定される。した がってこのような電着塗料液は好ましいとは考えられな \&。

\section{文献}

1) Reuss, Mem. Soc. Imp. Nat Moskou, 2, 327 (1809); Encyclopedia Britannica, 6, 226.

2) S. E. Shepard, L. W. Eberlin, India Rubber J., 70, 21 (1925); Ind. Eng. Chem., 17, 711 (1925).

3) F. A. Eliott, Chem. Met. Eng., 33, 358(1926); India Rubber J., 72, 32 (1926).

4) P. Klein, Trans. I. R. I., 4, 343 (1928); India Rubber J., 76, 874, 897 (1928); Rubber Chem. and Tech., 2, 278 (1929).

5) D. C. Henry, Proc. Roy. Soc., (London), A133, 106 (1931).

6) A. Johnson, J.G. Mackay, Preprint of Paper Submitted at Paris Conf., June, 1931, 6.

7) J. G. Mackay, Rubber Chem. and Tech., 5, 232 (1932).

8) C. L. Beal, Ind. Eng. Chem., 25, 609 (1933); Rubber Chem. and Tech., 6, 537 (1933).

9) N. Budiloff, Kautschuk, 9, 1, 20 (1933) ; Rubber Chem. and Tech., 6, 422 (1933).
17) G. C. Fink, M. Feinleib, Trans. Eloctro Chem. Soc., 94, 309 (1948).

18) Verwey and Overbeek "Theory of the Stability Lyophobic Colloid”, Elsevier, 1948.

19) Hardy and Schulze, "Colloid Science" 109, Oxford, (1949).

20) S. A. Troelstra, Philips Tech. Rev., 12, 293 (1951).

21) A. Goffey, “Corrosin” U. R. Evans (1 st. Ed).

22) T.D. Threadgold, Brit. Patent 716, 583(1954).

23) V. J. De Santis, F. L. Hunter U. S. Patent 2, 711, 980 (1951).

24) J. J. Shyne, Org. Fin., 17, 12 (1956).

25) B. Roy, J. Indian Chem. Soc., 33, 253 (1956).

26) J. K. Thomson, U. S. Patent 2, 956, 937 (1958).

27) Haseltine Lake \& Co., Brit. Patent 866, 780 (1961).

28) A. A. Thornton \& Co., Brit. Patent 884, 797 (1961).

29) Reddie \& Grose Brit. Patent. 899, 302 (1962).

30) Marks \& Clerk, Brit. Patent 933, 715 (1963).

31) BISRA Report $\mathrm{MW} / \mathrm{c} / 18 / 61$; Electroplating Metal Fin, 15, [4] 133 (1962).

32) J. P. Burden, V. M. Guy, Trans. Inst. of Metal Fin., 40, [3] 93 (1963).

33) Prod. Fin., 16, [4], 58 (1963)

34) Corrosion Tech., 1963 [4], 99.

35) Canad. Paint \& Varn., $1963[7], 61$.

36) W. M. Sawyer, S. J. Rehfeld, J. Phys. Chem., 67, 1973 (1963).

37) J. R. Berry, Paint Tech., 27, [12], 13 (1963).

38) K. H. Frangen, Farbe und Lack, 69, 898(1963).

39) J. R. Berry, Paint Tech., 28, [1], 24 (1964).

40) L. Tasker, J. D. Taylor, Paint oil and Colour J., 145 [3411], 457 (1964).

41) S.R.Finn, C.C. Mell, J. Oil and Colour Chemist's Assoc., 47, 219 (1964). 
42) J. R. Berry, Paint Tech., 28, [3], 53 (1964).

43) Prod. Fin., 17, [4], 75 (1964).

44) Prod. Fin., 17, [7], 50 (1964).

45) H. R. Crawford, Paint Oil and Colour J., 145, [3407] 249 (1964).

46) E. Hahn, Ind. Lackier Betrief, 32, [5], 155 (1964).

47) P. W. Sherwood, Paint Manuf., 34, (8), 49
(1964).

48) G. Génin, Peintures Pig. Vernis, 40, (6), 387 (1964).

49) Pailw Gaz. 120, 699 (1964).

40) Machine Shop Mag., 25, 346 (1964).

(1964 年 11 月 15 日 化学関係学協会連合研究発表: 会中央大学にて講演)

\section{色 材 協 会 誌 38 巻 8 号 (予 告)}

報 文

超微粒子分散性銅フタロシアニン系着色剂の研究（第 4 報） 堀口正二郎

(大日精化工業(株))

資 料

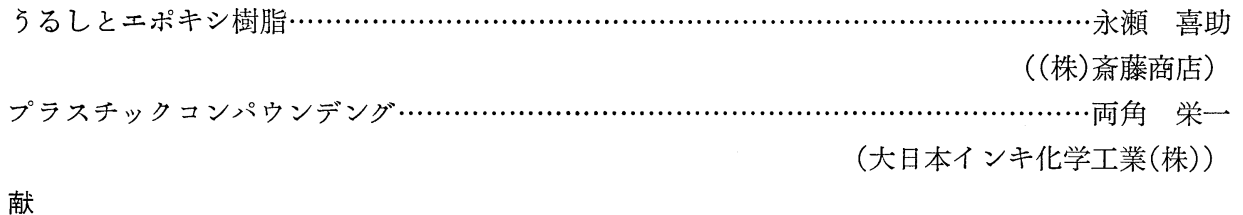

